\title{
Achieving sustainability through strategically driven CSR in the South African retail sector
}

\author{
Neeltje du Plessis and Anské F. Grobler \\ Communication Management Division, Department of Business Management, University of Pretoria, \\ Gauteng, South Africa
}

\begin{abstract}
The purpose of the research was to indicate how retailers, who operate under conditions of an imperfect democracy in a challenging and turbulent business environment, obtained triple bottom line sustainability by considering corporate social responsibility (CSR) activities as part of the strategic intent of the organisation. A qualitative comparative case study design was followed. Through the literature review in the first phase, three previously unrelated components, namely Warren's (2003) evolution of business legitimacy theory, Jensen's (2001) three descriptors of the company as an agent in society; and Holmström's (1997) social systemic Public Relations paradigm, were combined to develop a theoretical framework against which the websites and the annual and sustainability reports of three South African retailers were analysed in the second phase. Analyses were done at two levels: the degree to which community relations and governance issues were represented at strategic level and the achievement of specific impact objectives at technical level. All three retailers channelled CSR activities through either a foundation or a trust registered as a non-profit entity. This could be indicative of the importance assigned to their CRS initiatives. An ability to adapt to changes in the macro environment and surviving economic, political and social challenges was demonstrated.
\end{abstract}

Keywords Corporate social responsibility, evolution of business legitimacy, company as an agent in society, social systemic PR paradigm, triple bottom line, sustainability 


\section{Introduction}

"The most important part of corporate social responsibility is 'corporate'" (Immelt, cited in Warhurst, 2008). Kotler and Lee (2005:3) define corporate social responsibility (CSR) as "a commitment to improve community well-being through discretionary business practices and contributions of corporate resources". The perception of business corporations as agents in society is constantly changing to reflect the changing societal expectations represented by other stakeholder groups such as governments and community groups (Jensen, 2001). Traditionally, business organisations saw themselves as being responsible for delivering goods and services to the marketplace represented by customers, providing jobs and security to employees, rewarding investors with profit, complying with legislation and paying taxes to the government. For a long time this 'social contract' between business and society in stable capitalist societies was accepted and understood by all.

However, it is no longer acceptable for business to supply goods and services at a profit without contributing a part of that profit towards the empowerment of people in the community and the protection of the environment; hence the reference to the triple bottom line, which not only includes profit, but also people and the planet.

There is also a growing realisation that governments in developing economies cannot satisfy the vast economic and social needs of society in developing communities. This is especially true in the current international economic downturn. In fact, the factor that distinguishes most developing countries from first world countries is more often than not poverty (Steyn \& Herselman, 2005:155). Poverty, unemployment and crime are complex, interlinked issues. Poverty eradication programmes often focus on either skills development or job creation. When the beneficiaries of these programmes are able to support themselves and their families over the long term, their self-sufficiency is regarded as successful development which leads to sustainable development.

Sustainability is of particular importance on the African continent. Pratt $(2006$, cited in Botan \& Hazleton, 2006, p. 259) states: 
Africa's major challenge is sustainable development - the capacity of a nation's resources for renewal, for recovery from a wide range of ecological disturbances, and for retention of their ecological properties, all in ways that enable the management of those resources to meet current and future needs of people who use them.

Sustainability originates from the concept of managing the environment, which is aimed at directing how an organisation can survive without compromising the ecological, social and economic environment, to meet current and future requirements (Crane, Matten, \& Spencer, 2008, p. 56). Literature (Grunig, 1992; Steyn \& Puth, 2000) further suggests that to be successful and sustainable, corporate activities should be managed at a strategic level and be implemented with measurable tactical impact objectives in mind.

The theoretical statement put forward in this article is therefor that South African retailers, operating under conditions of an imperfect democracy in a turbulent business environment, and who view corporate social responsibility (CSR) as part of the organisation's strategic intent, will improve their chances of attaining economic, social and environmental sustainability.

Some scholarly research has been undertaken on CSR initiatives in Africa and particularly in South Africa (Dawkins \& Ngunjiri, 2008; Foundation for the Development of Africa, 1999; Irvin, 2002; Njenga \& Smit, 2007; Van den Ende, 2004), but no results could be found on how viewing CSR activities as part of the organisation's strategic intent can relate to triple bottom line sustainability.

Although the terms corporate social responsibility (CSR) and corporate social investment (CSI) are often used interchangeably in literature, it should be noted that the Foundation for the Development of Africa (FDA) views CSR as an intention and CSI as an action (Foundation for the Development of Africa, 1999). This possibly explains the popularity of the former and it is also the reason why it is the preferred term. 


\section{Research aim}

The aim of the research on which this article is based was to validate the theoretical statement put forward, namely motivating why organisations' CSR activities should be supported at a strategic level as part of the Board of Directors' strategic intent of the company. The research was conducted in two phases. The first phase comprised a thorough literature review in which three previously unrelated concepts, namely Warren's (2003) evolution of business legitimacy theory; Jensen's (2001) three descriptors of the company as an agent in society; and Holmström's (1997) social systemic public relations (PR) paradigm. These concepts were combined to form a theoretical framework against which the strategic intent of three South African retailers could be evaluated.

In the second phase Kotler and Lee's (2005, pp. 23-24) six well-established best practices of corporate social responsibility initiatives were used to analyse the three retailers' CSR activities at a technical level. The assumption that guided the empirical section of the research was that business organisations operate as open systems in a developing country under conditions of imperfect democracy.

The CSR programmes of three South African retailers (Pick n Pay, Mr Price and Woolworths), as reported on in their 2010 annual reports, 2010 annual sustainability reports and websites, were investigated to indicate the importance of viewing CSR as part of the organisation's strategic intent to achieve economic, social and environmental sustainability.

\section{Phase I: Theoretical framework}

This section is reported on in the following manner: Warren's (2003) evolution of business legitimacy theory explains the increased prominence of political, social and environmental issues in corporate decision making. Thereafter, Jensen's (2001) three concepts describing the development of the company as an agent in society are discussed. Specific attention is paid to the role public relations play in influencing the reputation of the business as an agent in society in each concept. The discussion, which concludes with a brief summary of Holmström's (1997) social systemic PR paradigm, provides an overview of how the changes in the macro 
environment also affect the perceptions of the way PR can contribute to organisational adaptation and decision making in a turbulent environment.

\subsection{The evolution of business legitimacy}

This theory states that normal determinants of government policy decisions shift from economic to environmental and social factors, according to changes in the macro environment which influences public opinion. Recent emphasis on corporate governance and the importance of stakeholder concerns, including transparent reporting initiatives, illustrates an attempt to balance financial performance against social accountability. Warren (2003) describes a cycle where government policy swings from mainly favouring business concerns to mainly favouring concerns raised by social and economic lobbyists.

During periods where business interests are seen as being paramount, businesses lobby successfully to bring pressure to bear on politicians. This effectively influences policy decisions to favour business activities. These periods are characterised by strong capitalist economic growth and a stable socio-political environment. Shareholders are considered to be the most important stakeholder group for business and PR activities are mainly concerned with lobbying and financial relations. The relationships with customers, employees and the media are limited to the influence they have on the financial success of the organisation. This is known as shareholder prominence.

However, according to Warren (2003), these periods of capitalist growth, determined by economic factors, eventually give rise to interest groups representing non-business owners, who are of the opinion that they fall further and further behind in not having their interests adequately served by economic growth. Their growing resentment criticises the capitalist system and its representative business institutions for not facilitating adequate redistribution mechanisms. Tensions increase especially during times of crisis - such as an economic depression or environmental changes as shown by the effects of global warming (Warren, 2003). During this period political structures start giving precedence to the interests of nonbusiness groups and cause a legitimisation crisis for business, questioning their 'licence to 
practise'. With non-business interests on the political agenda, socio-political forces override economic forces and this influences the legislative process. During this part of the cycle the social and environmental lobbyists are successful in finding favour from government policy makers.

In the wake of political changes from a nationalist government to a more representative socialist government in South Africa, South African examples of Warren's theory include legislation setting targets for broad-based black economic empowerment (BBBEE) and pressure from government to adapt manufacturing processes to cause less harm to the environment. These policy measures are especially important to high profit sectors such as mining and highly politicised issues such as ownership of media organisations. BBBEE regulations affect all sectors (including the retail sector) and many organisations now implement plans to develop and assist black-owned suppliers to become part of their supplier networks. BBBEE serves as a cornerstone of the current economic policy. As a result, many firms in South Africa have demonstrated their CSR by selling part of their equity to black empowerment organisations (Wolmarans \& Sartorius, 2009, p. 180).

As the cycle swings to the benefit of non-business groups, businesses lobbying activities carry less weight and have less influence on political decision making. This can be illustrated as shown in Figure 1.

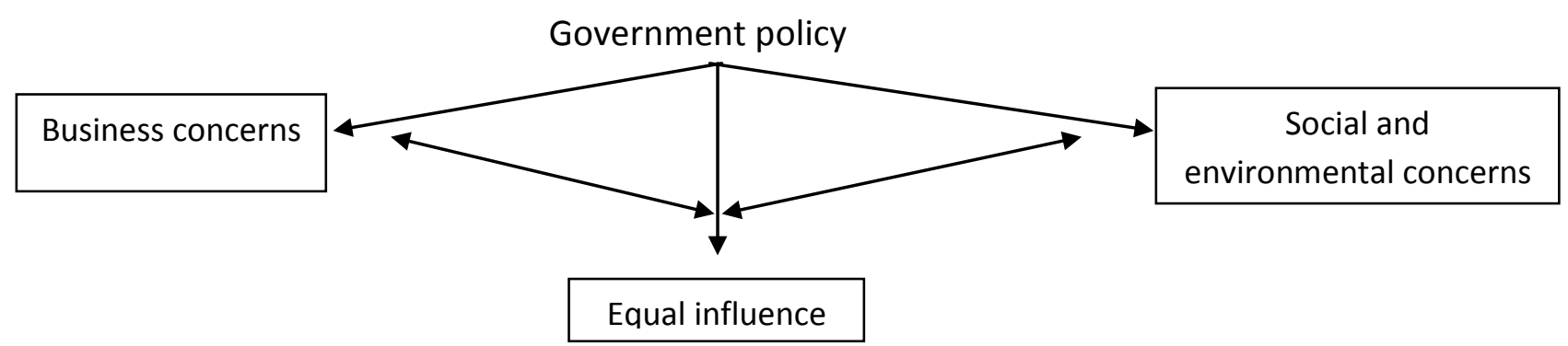

Fig. 1. Influence of lobbyist in government policy 
Jensen's (2001) three concepts of the company as an agent in society is now be related to Warren's (2003) evolution of business legitimacy as part of the discussion as to how PR can be used to influence an organisation's reputation as an agent in society.

\subsection{Concepts of the company as an agent in society}

Jensen (2001) uses the following three descriptors to assess the company's status as an agent in society: economic successfulness, social relevance, legal compliance and social responsibility. The discussion also refers to the appropriate PR model - according to Grunig's (1992) wellknown Excellence Theory - applied in two of Jensen's (2001) descriptors. These models are the one-way communication models of public information and publicity and the two-way communication models of asymmetry and symmetry (Grunig, 1992).

\subsubsection{The company is economically successful, but socially innocent}

Jensen's (2001) first descriptor indicates that there is a clear division of labour between economics and other institutions and disciplines. The company is considered to be socially innocent as it does not deal with questions of morality and values, but leaves these issues to institutions and disciplines such as the church and sociology. Management focuses on rational strategic planning related to market opportunities and the company follows clearly defined economic ends and contributes to the economic wealth in society (Jensen, 2001, p. 138). Jensen (2001) argues that the role of PR is very limited in this stage. The PR functions only through market-related activities such as sales promotion, product information and publicity. This corresponds with the one-way communication models of Grunig's (1992) Excellence Theory, namely publicity and public information models. In this stage the most important stakeholders are investors, suppliers, customers and employees.

\subsubsection{The company is economically successful and legal}

This descriptor views the market inadequate as being the only distribution system of goods according to the values and qualitative needs in society. Governments therefore repair market inefficiencies by legally based regulation of company activities. Laws are used to restrict companies from harming the common good while certain other business activities are 
supported. Examples of such restrictions are, on the one hand, regulations concerning health and safety in the workplace, restrictions on pollution levels, or the enforcement of employment equity as previously discussed. On the other hand, regulations could be passed to support export and job creation initiatives. Management now focuses on bounded rationality, strategic planning and adapting to regulations (Jensen, 2001, p. 138). The quest is for economic success as well as a legal compliance. This concept sees the corporate communication focus shifting from a pure shareholder view to emphasis on government relations through lobbying as an important PR technique. As pointed out in the previous discussion on the evolution of business legitimacy, the success of lobbying activities will depend on where the government policy favour lies at that stage.

\subsubsection{The company is economically successful, legal and responsible}

Jensen's (2001) final descriptor indicates a company that survives economically, abides by the law, exploits legal support, and voluntarily gives attention to demands from public discourse and institutionalised stakeholders. These demands transcend the scope of legality and hold the company responsible for values not connected to pure economic goals of contributing to the economic wealth in society, or to compliance and exploitation of legal support. Management goals in this stage become ambiguous and include legitimacy and responsibility to multiple values set by different agents. Corporate decision making is influenced not only by internal goals and priorities set by the market and government; it must also take into account issues raised in public discourses and by institutionalised stakeholders such as the mass media and activist groups. These external groups do not necessarily share the same values among themselves or with the company. The focus now shifts to value-based management, internal and external negotiations, value-defining processes and what Jensen (2001, p. 138) calls the "multiple bottom line". This stage sees the development of PR as a vital corporate function,

practising two-way symmetrical communication according to Grunig's Excellence Theory (1992).

In the next section Holmström's (1997) application of the reflective paradigm of Niklas Luhman to the PR domain to create the social systemic PR paradigm is explained to illustrate the 
influence of reflection and context regulation on the way corporations relate to their environments.

\subsection{Interpretation of the systems theory in the social systemic PR paradigm}

\subsubsection{Social systems described}

Social systems, which emerge when two or more persons' actions are connected, progress through informal, interactive systems to formalised organisational systems such as an organisation or corporation (Holmström, 1997). The social system thereby isolates itself from other systems and takes on its own 'life'. In this way it motivates and justifies itself through selective communication processes, to distinguish itself from the complex environment. Social systems are therefore self-creating and self-referential and create their own logic.

The foundation of a social system is shared meaning, which is used to define and limit the identity of the system (Holmström, 1997). Through this shared meaning, decisions are made regarding what will be included and excluded from the system, thus creating system boundaries. These boundaries are normative and can be opened through a process of acquiring and processing information on which to base decisions on opening or closing the system's boundaries. This cognitive decision making is determined by the specific logic of the system and it can therefore be stated that social systems observe and evaluate the world from their own logic and create their own worldview on which their decisions are based. Boundaries will only open if the system specifically decides to open it based on its own unique perception of reality. This perception is the result of the corporate culture and values combined with external pressure from legislation and pressure groups (Holmström, 1997).

\subsubsection{Reflection leading to the system's continued existence}

Social systems regulate themselves by continuously adjusting to each other through negotiation and mutual, decentralised control considering the idea of a common society in order to secure mutual interaction. This is referred to as context regulation based on mutual reflection. Reflection in this instance is a social systemic concept that describes the independence of the system as well as the interdependence between systems. In the first instance, reflection implies 
that the social system finds its identity by acting independently to secure autonomy. Secondly, it implies that a system understands its function as part of the environment of other social and functional systems and develops restrictions and coordinating mechanisms that will take other systems into account when making decisions. This function indicates the system's awareness of its social responsibility and its interdependence on other systems in its environment. The risk of reflection is exposure and sacrifice in the short term. In the long term, the reward is continued existence; corporate sustainability.

\subsubsection{Functional systems and symbolic media}

Holmström (1997) further indicates that social systems cluster together to form functional systems that share symbolic media. For example, the functional system of public communication shares the symbolic medium of social responsibility, which is the responsibility of the system to support the social order in the common society through socially acceptable behaviour. This symbolic medium is used to identify, classify and discuss themes that could put mutual strains on the functional system and other functional systems in its environment, and to play a main part in mutual, adjusting control. In other words, it identifies, prioritises and solves issues that have an impact on the system and its environment.

The functional system of PR is the coordinating mechanism that ensures self-control and combines the differentiated units in the complex context of the public communications system. This is achieved by means of the specific corporate activity that attends to building and maintaining relations between autonomous systems through the symbolic medium of social responsibility. This includes relations with different kinds of social systems in the organisational system's environment, for example employees, consumers, mass media and pressure groups. Its purpose can be seen to secure the independence of the functional system by nurturing its interdependence with other systems in the environment (Holmström, 1997).

\subsubsection{Reflective and expressive tasks}

According to Holmström (1997), PR therefore has two clearly discernible tasks: the reflective task which furthers reflection within the system, thus resulting in the corporate identity, and 
the expressive task which furthers reflection on the system within the other systems in the environment, represented by corporate image and reputation perceptions.

The context-regulated social order is a precondition for autonomy of an organisational system. It considers self-control as a substitute for law as the main regulator which encourages organisations not to act on their options and contingencies freely, but to adjust according to the idea of collective social responsibility. Legal sanctions are therefore supplemented by voluntary mutual sanctions imposed by participants to prevent interaction with systems that do not take collective social responsibility into account when making decisions (Holmström, 1997).

Reflection on social responsibility (the symbolic medium of the public communication system) thus becomes a precondition for interaction (participation), interdependence and context (the mutual adaptation of systems through negotiation, decentralisation of control and consideration of the idea of common society and social order to secure interaction) and ultimately for autonomy that ensures the independence and the long-term survival of the organisational system.

\section{Combining theoretical concepts for a framework to evaluate strategic intent}

The summary of the relation between the viewpoints of Warren (2003), Jensen (2001) and Holmström (1997), as provided in Table 1, was used as a framework of theoretical concepts against which the strategic intent of the retailers was evaluated. This summary also indicates the different PR models developed by Grunig (1992) throughout the analysis. The last category, which indicates the level of PR influence as technical, managerial or strategic, refers to the roles distinguished in Steyn and Puth's (2000) research on the roles PR practitioners play in South African organisations. 


\section{Table 1.}

Framework of theoretical concepts for evaluating strategic intent of retailers

\begin{tabular}{|c|c|c|c|}
\hline Analysis category & $\begin{array}{l}\text { Economically } \\
\text { successful }\end{array}$ & $\begin{array}{l}\text { Economically } \\
\text { successful and legal }\end{array}$ & $\begin{array}{l}\text { Economically } \\
\text { successful, legal and } \\
\text { responsible }\end{array}$ \\
\hline $\begin{array}{l}\text { Role of PR according } \\
\text { to Jensen (2001) and } \\
\text { Grunig (1992) }\end{array}$ & $\begin{array}{l}\text { Very limited } \\
\text { One-way } \\
\text { communication: } \\
\text { publicity and public } \\
\text { information models }\end{array}$ & $\begin{array}{l}\text { Lobbying and public } \\
\text { affairs } \\
\text { Research: } \\
\text { forecasting } \\
\text { Limited two way } \\
\text { asymmetrical model }\end{array}$ & $\begin{array}{l}\text { Negotiate, adapt, } \\
\text { understand, and do } \\
\text { extensive research on } \\
\text { stakeholder } \\
\text { perceptions } \\
\text { Reflect on identity } \\
\text { (independence) and } \\
\text { image } \\
\text { (interdependence) } \\
\text { Two way symmetrical } \\
\text { communication }\end{array}$ \\
\hline Stakeholder focus & $\begin{array}{l}\text { Shareholders / } \\
\text { owners }\end{array}$ & $\begin{array}{l}\text { Government and } \\
\text { media }\end{array}$ & $\begin{array}{l}\text { Extended stakeholder } \\
\text { focus: includes natural } \\
\text { environment and } \\
\text { future generations (as } \\
\text { suggested by Zsolnai, } \\
2006 \text { ) }\end{array}$ \\
\hline $\begin{array}{l}\text { Main drivers for } \\
\text { corporate decision } \\
\text { making }\end{array}$ & $\begin{array}{l}\text { Financial profit / } \\
\text { money }\end{array}$ & $\begin{array}{l}\text { Legal compliance } \\
\text { Legal sanctions and } \\
\text { reward-driven } \\
\text { Search opportunities } \\
\text { to exploit legislation }\end{array}$ & $\begin{array}{l}\text { Values driven } \\
\text { Sees itself as legitimate } \\
\text { part of society } \\
\text { Emphasis on } \\
\text { community relations } \\
\text { Sees expansion of CSR } \\
\text { activities }\end{array}$ \\
\hline $\begin{array}{l}\text { Government policy } \\
\text { favours (Warren, } \\
2001 \text { ) }\end{array}$ & Business & $\begin{array}{l}\text { Social and } \\
\text { environmental } \\
\text { lobbies become } \\
\text { more important } \\
\text { Increase in } \\
\text { legislation such as } \\
\text { AA; BBBEE; Pollution } \\
\text { restrictions } \\
\text { SMME creation (tax } \\
\text { rebates) }\end{array}$ & $\begin{array}{l}\text { Transcends } \\
\text { government } \\
\text { regulations } \\
\text { Voluntary self-control } \\
\text { For example: King III; } \\
\text { Global Reporting } \\
\text { Initiative (GRI) } \\
\text { guidelines }\end{array}$ \\
\hline Level of PR influence & Technical & Limited managerial & $\begin{array}{l}\text { Managerial and } \\
\text { strategic }\end{array}$ \\
\hline
\end{tabular}


The discussion now focuses on the definition of CSR in the South African context. This will link the theoretical discussion to the case study analysis of the three retailers' strategic intent and implementation of their CSR programmes.

\section{Defining CSR: A South African interpretation}

The current global economic crisis, together with the general distrust and lack of confidence in business after a number of corporate scandals at board level (Hilb, 2006, p. 3) has necessitated actions to assist business in becoming more transparent and complying with corporate governance rules. Examples of these governance rules include the Sarbanes-Oxley Act (SOX) (USA), the Cadbury Report (UK) and the King Reports (South Africa). In South Africa the third report on corporate governance (King III Report) was necessary because of the new Companies Act no. 71 of 2008 and because of changes in international governance trends. The King III Report has become internationally recognised as it advocates for an integrated approach to corporate governance, over and above the financial and regulatory aspects.

The King III Report (Institute of Directors, 2009, p. 118) defines CSR as:

[t]he responsibility of the company for the impacts of its decisions and activities on society and the environment, through transparent and ethical behaviour that: contributes to sustainable development, including health and the welfare of society; takes into account the legitimate interests and expectations of stakeholders; is in compliance with applicable law and consistent with international norms of behaviour; and is integrated throughout the company and practiced in its relationships.

The analysis of this definition (Table 2) illustrates how the preceding theoretical discussion is represented therein. The author's emphasis is indicated by bold typeface. 
Table 2.

Analysis of King III definition of CSR

\begin{tabular}{|c|c|c|}
\hline Source & Theoretical influence & $\begin{array}{l}\text { King III CSR definition: } \\
\text { "Corporate responsibility is ... }\end{array}$ \\
\hline Warren (2001) & Extended stakeholder focus & $\begin{array}{l}\text { The responsibility of the company for impacts } \\
\text { of its decisions and activities on society and } \\
\text { the environment }\end{array}$ \\
\hline $\begin{array}{l}\text { Holmström } \\
\text { (1997) }\end{array}$ & $\begin{array}{l}\text { System boundaries are open; } \\
\text { reports on activities }\end{array}$ & Through transparent and ethical behaviour \\
\hline $\begin{array}{l}\text { Jensen (2001) } \\
\text { and Warren } \\
(2005)\end{array}$ & $\begin{array}{l}\text { Sees itself as legitimate part } \\
\text { of society } \\
\text { Emphasis on community } \\
\text { relations sees expansion of } \\
\text { CSR activities }\end{array}$ & $\begin{array}{l}\text { That: contributes to sustainable development, } \\
\text { including health and welfare in society }\end{array}$ \\
\hline Jensen (2001) & $\begin{array}{l}\text { Economically successful: } \\
\text { focus remains on core } \\
\text { business }\end{array}$ & $\begin{array}{l}\text { Takes into account legitimate interests and } \\
\text { expectations of stakeholders }\end{array}$ \\
\hline Jensen (2001) & $\begin{array}{l}\text { Legal compliance } \\
\text { Legal sanctions and reward- } \\
\text { driven } \\
\text { Search opportunities to } \\
\text { exploit legislation }\end{array}$ & $\begin{array}{l}\text { Is in compliance with applicable law and } \\
\text { consistent with international norms of } \\
\text { behaviour }\end{array}$ \\
\hline $\begin{array}{l}\text { Jensen (2001) } \\
\text { and } \\
\text { Holmström } \\
\text { (1997) }\end{array}$ & $\begin{array}{l}\text { Negotiate, adapt, } \\
\text { understand, and do extensive } \\
\text { research on stakeholder } \\
\text { perceptions } \\
\text { Reflect on identity } \\
\text { (independence) and image } \\
\text { (interdependence) }\end{array}$ & $\begin{array}{l}\text { And is integrated throughout the company } \\
\text { and practiced in its relationships" }\end{array}$ \\
\hline
\end{tabular}

This analysis indicates the strategic perspective accorded to CSR in the South African context. The discussion now moves to the more technical perspective of CSR as offered by Kotler and Lee (2005). Both the strategic and the technical perspectives will then be used together with the preceding theoretical framework to inform the case study analysis. 


\section{Phase II: Technical level analysis}

Kotler and Lee's (2005:23-24) six categories in which businesses' CRS activities generally fall are discussed to facilitate the analysis of the three selected retailers' CSR activities at a technical level:

\subsection{Cause promotion: Promoting a worthy cause}

Cause promotion is described by Kotler and Lee (2005, p. 23) as a situation where "[a] corporation provides funds, in-kind contributions or other corporate resources to increase awareness and concern about a social cause or to support fundraising, participation or volunteer recruitment for a cause". Examples of this would be advertising to build awareness or participating in activities that underline a social cause.

\subsection{Cause-related marketing: Marketing a worthy cause}

Cause-related marketing is described as involving activities that focus mainly on product or service sales, where a company commits to making a contribution or donating a percentage of revenues to a specific worthy cause based on product unit sales (Kotler \& Lee, 2005, p. 23). Cause-related marketing usually runs for a specific time and can be clearly linked to a charity or an event (i.e. a disaster relief effort) that the organisation chooses to support. The public has the option of supporting the charity while doing their grocery shopping or fulfilling personal needs. This makes cause-related marketing particularly relevant in an age where more and more people are pausing to think about the consequences of each purchase they make (Collins, 1993, p. 48).

\subsection{Corporate social marketing: Behaviour change campaigns}

This type of initiative focuses on supporting the development and/or implementation of a behaviour change campaign intended to improve public health, safety, the environment, or community well-being (Kotler \& Lee, 2005, p. 23). An example of this kind of support would be involvement in anti-smoking campaigns. 


\subsection{Community volunteering: Employees donating time and talents}

Kotler and Lee (2005:24) define community volunteering as a situation where "corporations support and encourage employees and industry partners and/or franchise members to volunteer time to support local community organisations and causes". A company could, therefore, thus support a social cause and be visibly active in a developing community. Firms could encourage their workforce to apply their unique set of technical, financial and legal knowledge to these initiatives (Lewis, 2008). An example would be a firm that adopts a retirement home and then encourages employees to become actively involved in its activities.

\subsection{Corporate philanthropy: Donating to a charity}

Philanthropy is a traditional type of social investment where a company makes a direct contribution to charity or a cause by means of cash grants, donations and/or in-kind services (Kotler \& Lee, 2005, p. 23). Corporate philanthropy can involve providing cash donations, offering grants, awarding scholarships, donating products and services, providing technical expertise, allowing the use of facilities and distribution channels as well as offering utilisation of equipment.

\subsection{Socially responsible business practices: Moral and ethical business practices}

Kotler and Lee $(2005$, p. 24) describe this aspect as a corporation that "adopts and conducts discretionary business practices and investments that support social causes to improve community well-being and protect the environment". Examples would include ensuring that suppliers comply with environmentally friendly practices, recycling and energy-saving processes and fair employment policies.

As stated previously, the strategic and the technical perspectives were used with the theoretical framework developed in the first part of the research to evaluate the strategies and programmes of the three selected retailers to illustrate the synthesis of theories used to construct the framework. 


\section{Case study analysis}

Comparative case study analysis was undertaken to measure the strategic intent of Pick n Pay, Mr Price and Woolworths against the theoretical concepts summarised in Table 1. A case study technique was selected for its descriptive purposes (Babbie \& Mouton, 2001, p. 281; Zikmund, 2003, p. 116) as it provides "valuable insight for problem solving, evaluation and strategy" (Cooper \& Schindler, 2001, p. 138). Since this approach places emphasis on detail and provides an in-depth analysis of a few instances only, its results cannot easily be generalised (Cooper \& Schindler, 2001, pp. 137-138).

The profiles of the chosen retailers are provided in Table 3.

Table 3.

Profile of retailers

\begin{tabular}{|l|l|l|l|}
\hline \multicolumn{1}{|c|}{ Background } & \multicolumn{1}{|c|}{ Mr Price } & \multicolumn{1}{c|}{ Pick n Pay } & \multicolumn{1}{c|}{ Woolworths } \\
\hline Started & $\begin{array}{l}1885 \\
\text { (as John Orr Holdings) }\end{array}$ & 1967 & 1931 \\
\hline $\begin{array}{l}\text { Number of } \\
\text { stores }\end{array}$ & $\begin{array}{l}962 \\
\text { Mr Price and Mr Price } \\
\text { Home }\end{array}$ & $\begin{array}{l}794 \\
\text { Stores and franchises }\end{array}$ & $\begin{array}{l}538 \\
\text { Stores and } \\
\text { franchises }\end{array}$ \\
\hline $\begin{array}{l}\text { Number of } \\
\text { employees }\end{array}$ & 17300 & 49000 & 20000 \\
\hline $\begin{array}{l}\text { Multi-national } \\
\text { involvement }\end{array}$ & Africa & Africa and Middle East & $\begin{array}{l}\text { Africa, Australia and } \\
\text { New Zealand }\end{array}$ \\
\hline $\begin{array}{l}\text { Products } \\
\text { Mr Price: Clothing } \\
\text { Mr Price Home: Home } \\
\text { accessories and linen }\end{array}$ & $\begin{array}{l}\text { Food and electrical } \\
\text { equipment for the home } \\
\text { Clothing }\end{array}$ & $\begin{array}{l}\text { Clothing } \\
\text { Food }\end{array}$ \\
\hline $\begin{array}{l}\text { Non-profit CSR } \\
\text { model }\end{array}$ & RedCap Foundation & $\begin{array}{l}\text { Ackerman Pick } \mathrm{n} \text { Pay } \\
\text { Foundation }\end{array}$ & Woolworths Trust \\
\hline
\end{tabular}

\subsection{Discussion}

The strategic intent as described in the retailers' 2010 annual reports was analysed according to the categories identified from the theoretical discussion. Table 4 provides a summary of the 
categories as they apply to Jensen's (2001) economically successful, legal and responsible organisation, according to table 1.

\section{Table 4.}

Extract from summary of theoretical concepts in Table 1

\begin{tabular}{|l|l|}
\hline \multicolumn{1}{|c|}{ Analysis category } & \multicolumn{1}{|c|}{ Economically successful, legal and responsible } \\
\hline $\begin{array}{l}\text { Role of PR according } \\
\text { to Jensen (2001) and } \\
\text { Grunig (1992) }\end{array}$ & $\begin{array}{l}\text { Negotiate, adapt, understand, and do extensive research on } \\
\text { stakeholder perceptions } \\
\text { Reflect on identity (independence) and image (interdependence) } \\
\text { Two-way symmetrical communication }\end{array}$ \\
\hline Stakeholder focus & $\begin{array}{l}\text { Extended stakeholder focus: includes natural environment and future } \\
\text { generations }\end{array}$ \\
\hline $\begin{array}{l}\text { Main drivers for } \\
\text { corporate decisions }\end{array}$ & $\begin{array}{l}\text { Values driven } \\
\text { Sees itself as legitimate part of society } \\
\text { Emphasis on community relations sees expansion of CSR activities }\end{array}$ \\
\hline $\begin{array}{l}\text { Government policy } \\
\text { favours (Warren, } \\
\text { 2003) }\end{array}$ & $\begin{array}{l}\text { Transcends government regulations } \\
\text { Voluntary self-control } \\
\text { For example: King III; GRI guidelines }\end{array}$ \\
\hline Level of PR influence & Managerial and strategic \\
\hline
\end{tabular}

Table 5 provides a summary of the analysis of the strategic intent of the retailers as extracted from the corporate websites and annual reports for 2010. 
Table 5.

Analysis of strategic intent of retailers

\begin{tabular}{|c|c|c|c|}
\hline Analysis category & Mr Price & Pick n Pay & Woolworths \\
\hline $\begin{array}{l}\text { Role of PR } \\
\text { according to } \\
\text { Jensen (2001) and } \\
\text { Grunig (1992) }\end{array}$ & $\begin{array}{l}\text { Does research on } \\
\text { stakeholder } \\
\text { perceptions } \\
\text { Strong corporate } \\
\text { identity and image }\end{array}$ & $\begin{array}{l}\text { Does research on } \\
\text { stakeholder } \\
\text { perceptions } \\
\text { Strong corporate } \\
\text { identity and image }\end{array}$ & $\begin{array}{l}\text { Does research on } \\
\text { stakeholder } \\
\text { perceptions } \\
\text { Strong corporate } \\
\text { identity and image }\end{array}$ \\
\hline Stakeholder focus & $\begin{array}{l}\text { Extended stakeholder } \\
\text { focus: Includes } \\
\text { environmental issues } \\
\text { and future generations } \\
\text { in planning and } \\
\text { strategy }\end{array}$ & $\begin{array}{l}\text { Extended stakeholder } \\
\text { focus: Includes } \\
\text { environmental issues } \\
\text { in planning and } \\
\text { strategy }\end{array}$ & $\begin{array}{l}\text { Extended stakeholder } \\
\text { focus: Includes } \\
\text { environmental issues } \\
\text { in planning and } \\
\text { strategy }\end{array}$ \\
\hline $\begin{array}{l}\text { Main drivers for } \\
\text { corporate } \\
\text { decisions }\end{array}$ & $\begin{array}{l}\text { Profit and values } \\
\text { driven } \\
\text { Part of society } \\
\text { Considers CSR to be } \\
\text { very important }\end{array}$ & $\begin{array}{l}\text { Profit and values } \\
\text { driven } \\
\text { Part of society } \\
\text { Considers CSR to be } \\
\text { very important }\end{array}$ & $\begin{array}{l}\text { Profit and values } \\
\text { driven } \\
\text { Part of society } \\
\text { Considers CSR to be } \\
\text { very important }\end{array}$ \\
\hline $\begin{array}{l}\text { Government } \\
\text { policy favours } \\
\text { (Warren, 2003) }\end{array}$ & $\begin{array}{l}\text { Complies with all } \\
\text { relevant legislation } \\
\text { Voluntary self-control: } \\
\text { King III and GRI } \\
\text { guidelines }\end{array}$ & $\begin{array}{l}\text { Complies with all } \\
\text { relevant legislation } \\
\text { Voluntary self-control: } \\
\text { King III and GRI } \\
\text { guidelines } \\
\text { Very strict code of } \\
\text { conduct for all } \\
\text { employees }\end{array}$ & $\begin{array}{l}\text { Complies with all } \\
\text { relevant legislation } \\
\text { Voluntary self-control: } \\
\text { King III and GRI } \\
\text { guidelines }\end{array}$ \\
\hline $\begin{array}{l}\text { Level of PR } \\
\text { influence }\end{array}$ & $\begin{array}{l}\text { Managerial, however } \\
\text { sustainability and risk } \\
\text { management } \\
\text { (including reputation } \\
\text { risk) represented at } \\
\text { Board level } \\
\text { Stakeholder } \\
\text { relationships are } \\
\text { reported on in the } \\
\text { annual reports }\end{array}$ & $\begin{array}{l}\text { Managerial, however } \\
\text { sustainability and risk } \\
\text { management } \\
\text { (including reputation } \\
\text { risk) represented at } \\
\text { Board level } \\
\text { Stakeholder } \\
\text { relationships are } \\
\text { reported on in the } \\
\text { annual reports }\end{array}$ & $\begin{array}{l}\text { Managerial, however } \\
\text { sustainability and risk } \\
\text { management } \\
\text { (including reputation } \\
\text { risk) represented at } \\
\text { Board level } \\
\text { Stakeholder } \\
\text { relationships are } \\
\text { reported on in the } \\
\text { annual reports }\end{array}$ \\
\hline
\end{tabular}


All three retailers can be classified as economically successful, legal and responsible according to the concepts described by Jensen (2001).

However, strategy needs to follow through to implementation. In the next section the CSR programmes of the three retailers are analysed according to the categories provided by Kotler and Lee (2005).

\subsection{Analysis of CSR programmes}

Table 6.

Analysis of CSR programmes of retailers

\begin{tabular}{|l|l|l|l|l|l|l|}
\hline & $\begin{array}{l}\text { Cause } \\
\text { promotion }\end{array}$ & $\begin{array}{l}\text { Cause- } \\
\text { related } \\
\text { marketing }\end{array}$ & $\begin{array}{l}\text { Corporate } \\
\text { social } \\
\text { marketing }\end{array}$ & $\begin{array}{l}\text { Community } \\
\text { volunteerism }\end{array}$ & $\begin{array}{l}\text { Corporate } \\
\text { philanthropy }\end{array}$ & $\begin{array}{l}\text { Socially } \\
\text { responsible } \\
\text { business } \\
\text { practices }\end{array}$ \\
\hline $\begin{array}{l}\text { Cause } \\
\text { promotions }\end{array}$ & $\begin{array}{l}\text { Mr Price (4) } \\
\text { WW (1) }\end{array}$ & & & Mr Price (1) & Mr Price (1) & \\
\hline $\begin{array}{l}\text { Cause-related } \\
\text { marketing }\end{array}$ & & WW (3) & & & Mr Price (1) & \\
\hline $\begin{array}{l}\text { Corporate } \\
\text { social } \\
\text { marketing }\end{array}$ & & $(1)$ & & & & \\
\hline $\begin{array}{l}\text { Community } \\
\text { volunteerism }\end{array}$ & $\mathrm{Pn} \mathrm{P(1)}$ & & & & Mr Price (1) & \\
\hline $\begin{array}{l}\text { Corporate } \\
\text { philanthropy }\end{array}$ & & & & & & \\
\hline $\begin{array}{l}\text { Socially } \\
\text { responsible } \\
\text { business } \\
\text { practices }\end{array}$ & & & & & & \\
\hline
\end{tabular}

Programmes supported by Mr Price and the RedCap Foundation focus mainly on youth development through early childhood development, life skills transfer and sport development, 
as well as on providing internship opportunities in its stores and distribution centres. They also partner with various organisations such as Dell computers, Durban University of Technology and UNICEF. Philanthropic actions include donating sale stock and returned stock to charitable organisations and encouraging staff and associates to donate money and time to causes which they champion through their CSR activities (Mr Price, 2010; RedCap Foundation, 2010).

Pick $\mathrm{n}$ Pay and the Ackerman Pick $\mathrm{n}$ Pay Foundation focus strongly on environmental issues in their business practices. These organisations are also concerned with sustainable agriculture and small business development. This includes a strong focus on enhancing and development entrepreneurship and self-reliance skills to provide sustainable small businesses to grow and provide employment opportunities (Pick n Pay, 2010).

Woolworths and the Woolworths Trust focus strongly on environmental issues combined with programmes focussed on the development and support of orphaned and vulnerable children, and food security and nutritional issues in developing communities. They have a very well supported cause-related marketing programme which allows customers to become involved by choosing loyalty scheme type cards which will donate a percentage of money spent on purchases to a school, village or an NGO that focuses on environmental issues of the customer's choice (Woolworths Holdings Ltd, 2010; Woolworths Trust, 2010; Woolworths, 2010).

\section{Conclusions}

At a strategic level, it was found that all three retailers subscribed to socially responsible business practices that involved programmes to reduce their environmental impact, transparent governance practices as required by law and voluntary codes such as the King III report. It is clear that the three South African retailers mainly used socially responsible business practices in their corporate organisations and that they acted as economically successful, legal and responsible companies. They all considered sustainability issues to be important enough to be represented at Board level. 
At a technical level, these retailers implemented some of the CSR categories suggested by Kotler and Lee (2005), but not all of them. The categories that were used the most were cause promotion and cause-related marketing, while all three also had elements of philanthropy and employee volunteerism in their programmes. All three non-profit models also implemented programmes that used combinations of the CSR categories. CSR programmes were also often implemented in partnership with governmental departments and/or NGOs.

The theoretical statement put forward at the beginning of this article was that South African retailers operating under conditions of an imperfect democracy in a turbulent business environment, and who view CSR as part of the organisation's strategic intent, will improve their chances of attaining economic, social and environmental sustainability. This statement can be considered to be valid for all three retailers discussed in this article. The analysis of their strategic intent showed them to be economically successful, legal and responsible. All three retailers incorporated sustainability issues in their decision making at the highest level, and the implementation of these decisions at a technical level through the CSR activities of their foundations/trust contributed to social and environmental sustainability.

The research expanded on the debate regarding the value of CSR activities to benefit business, society and the environment. The researchers combined Warren's (2003) evolution of business legitimacy theory, which explains the increased prominence of political, social and environmental issues in corporate decision making, with Jensen's (2001) three concepts, which describe the development of the company as an agent in society, with Holmström's (1997) social systemic PR paradigm. Specific attention was paid to the role of PR in influencing the reputation of the business as an agent in society in each concept. This discussion provided an overview of how the changes in the macro environment also affect the perceptions of the way PR can contribute to organisational adaptation and decision making in a turbulent environment. The resultant framework was used to evaluate the strategic intent of the retailers. Finally, Kotler and Lee's (2005, p. 23-24) six well-established best practices of corporate social responsibility initiatives were used to analyse their CSR activities at a technical level. The findings that all three South African retailers managed to sustain their businesses over several 
generations may also contribute to business executives' appreciation of the way in which CSR strategies and programmes can contribute to triple bottom line corporate sustainability in developing contexts. A better understanding of how corporate managers make CSR decisions can help NGOs and community organisations to structure proposals for financial support more successfully.

South Africa is not the only case in point. Further investigation needs to be done in the other developing economies of the BRICS countries (Brazil, Russia, India and China). In developed countries the financial downturn also forces large international corporates to engage their corporate social responsibilities strategically to help them manage their risks, responsibilities and reputations. The social development involvement of companies is crucial, not only for business sustainability (licence to practise), but also for the sustainability of the environment (social and natural). It is therefore finally argued that as budgets tighten "we will see investments targeted to help companies manage their risks, responsibilities, and reputation" (Warhust, 2008). Only then can the most important part of corporate social responsibility be 'corporate'. 


\section{References}

Babbie, E. R. \& Mouton, J. (2001). The Practice of Social Research. Cape Town, SA: Oxford University Press.

Botan, C.H. \& Hazleton, V. (Eds.), Public Relations Theory II (pp.249-277). Hillside, NJ: Lawrence Erlbaum Associates.

Collins, M. (1993).Global Corporate Philanthropy - Marketing Beyond the Call of Day. European Journal of Marketing, 27(2), 46-58.

Cooper, D. R. \& Schindler, P. S. (2001). Business Research Methods. New York: McGraw-Hill.

Crane, A., Matten, D. \& Spencer, L.J. (2008). Corporate Social Responsibility: Readings and Cases in a Global Context. New York: Routledge.

Dawkins, C. \& Ngunjiri, F.W. (2008).Corporate social responsibility reporting in South Africa. Journal of Business Communication. 45(3), 286-307.

Foundation for the Development of Africa. (1999). An Introduction to Corporate Social Investment. http://www.foundation-developmentafrica.org/africa social investment/csi introduction.htm. Retrieved 15.09.09.

Grunig, J.E. (ed.). (1992). Excellence in Public Relations and Communication Management. Hillsdale, New Jersey: Lawrence Erlbaum Associates Hopkins.

Hilb, M. 2006. New corporate governance: successful board management tools. 2nd ed. Switzerland: Springer.

Holmström, S. (1997). The Inter-subjective and the Social Systemic Public Relations Paradigms. Journal of Communication Management. 2(1), 24-39.

Immelt, J. (2008), in Warhurst, A. The future of corporate philanthropy.

http://www.businessweek.com/globalbiz/content/dec2008/gb2008128 757524.htm Retrieved 31.08.09. 
Institute of Directors (IoD). (2009). King III Report on Corporate Governance. South Africa: Institute of Directors.

Irvin, R. (2002). Corporate social investment and branding in the new South Africa. Brand Management, 10(4), 303-311.

Jensen, I. (2001). Public Relations and Emerging Functions of the Public Sphere: An Analytical Framework. Journal of Communication Management, 6(2), 133-147.

Kotler, P. \& Lee, N. (2005).Corporate Social Responsibility: Doing the Most Good for Your Company and Your Cause. New Jersey: John Wiley and Sons.

Lewis, I. (2008). Fostering Corporate Community Involvement. http://www.sovereignpublications.com/eco-art-fostering.htm Retrieved 31.08.09.

Mr Price. (2010). Mr Price Annual Report 2010.http://www.mr.price.co.za Retrieved 16.05.11.

Njenga, S. \& Smit, A. (2007).Leading the way through CSI: A Guidebook for Corporate Social Investment Practitioners. South Africa: Knowres Publishing.

Pick n Pay. (2010). Pick n Pay Annual Report 2010. http://www.picknpay.co.za Retrieved 14.05.10.

RedCap Foundation. (2010). RedCap Foundation Annual Report 2010. http://www.mr.price.co.za Retrieved 16.05.11.

Steyn, B. \& Puth, G. (2000). Corporate Communication Strategy. Sandown, SA: Heinemann Publishers.

Steyn, C.E. \& Herselman, J.E. (2005). Trace Elements in Developing Countries Using South Africa as a Case Study. Communications in Soil Science and Plant Analysis. 36, 155-168.

Van den Ende, L. (2004). Corporate Social Responsibility in South Africa: Fact or Fiction. Dissertation submitted in partial fulfilment of the requirements for the degree Magister 
Commercii in Business Management in the Faculty of Economic and Management Sciences at Rand Afrikaans University, SA.

Warhurst, A. (2008). The future of corporate philanthropy.

http://www.businessweek.com/globalbiz/content/dec2008/gb2008128 757524.htm Retrieved 31.08.09.

Warren, R. C. (2003). The Evolution of Business Legitimacy. European Business Review, 15(3), 153-163.

Wolmarans, H. \& Satorius, K. 2009. Corporate Social Responsibility: The Financial Impact of BEE Transaction in South Africa. p180.

Woolworths (2010). Good Business Journey Report 2010. http://www.woolworths.co.za Retrieved 14.05.10.

Woolworths Holdings Limited. (2010). Corporate Profile. http://www.woolworths.co.za Retrieved 14.05.10.

Woolworths Trust (2010). Woolworths Trust. http://www.woolworths.co.za Retrieved 14.05.10.

Zikmund, W. G. (2003). Business Research Methods. Mason, OH: Thomson/South-Western.

Zsolnai, L. (2006). Extended Stakeholder Theory. Society and Business Review, 1(1), 37-44. 